\title{
GENETIC ANALYSIS OF GRAIN YIELD ATTRIBUTES AND PROTEIN CONTENT IN BREAD WHEAT UNDER DIFFERENT NITROGEN FERTILIZATION LEVELS.

\author{
Gebrel,E.M.A.H. ${ }^{1}$;R.A.Ramadan ${ }^{1}$;E.M.Mahgoub ${ }^{2}$;A.A.Mahmod ${ }^{2}$ and
} \\ Eman.M.M.Sadk ${ }^{1}$
}

1-Wheat Research Section, Field Crops. Res. Inst. Agric. Res. Cent., Giza, Egypt.

2-Genetics Dept., Fac. Agric., Zagazig Univ., Zagazig, Egypt.

\section{ABSTRACT}

Six diverse wheat cultivars (Triticum aestivum L.) were used in a partial-diallel crosses to produce $15 F_{1}$, hybrids. Genetical analysis and heritability, was estimated for days to heading, days to maturity, grain filling period, plant height, spike length, number of spikes /plant, 1000-grain weight, number of kernels per spike, grain yield/ plant and grain protein content. Mather and Jinks (1971) and Hayman(1954 a and b) methods were used to estimate the genetic parameters for studied characters. Significant mean squares were obtained for genotypes, parents and crosses for all traits studied under the three nitrogen levels. Thus, the parental cultivars displayed enough of genetic variability. The significant of mean squares for parents vs. crosses provide evidence for heterosis. Moreover, nitrogen mean squares were significant indicating that these characters behaved differently from one nitrogen level to another. The local wheat cultivar Shandaweel1 $\left(P_{3}\right)$ was superior for giving higher number of grains/spike, 1000-grain weight and grain protein content \% while Gemmeiza9 $\left(P_{4}\right)$ was the best for giving more number of spikes/plant and grain yield. Meanwhile the cross combination (Shandaweel1×Gemmeiza9 gave the heaviest 1000-grain weight ant the maximum value of number of grains/spike and grain yield /plant was obtained by the cross $\left(P_{1} \times P_{5}\right)$. These results hold true under the three nitrogen levels. The additive genetic variances (D) were significant for most of studied traits under three nitrogen fertilization levels. Significant values for the dominance components $(\mathrm{H} 1)$ were obtained for all traits under three nitrogen fertilizer levels. Values of $(\mathrm{H} 1)$ were larger in magnitude than their respective (D) ones for all traits under three nitrogen levels. Values of $\mathrm{H} 2$ were found to be smaller than $\mathrm{H} 1$ for all traits under the three nitrogen levels. Studies on degree of dominance revealed the presence of over dominance for days to maturity, grain filling period, plant height, spike length, number of grains per spike, grain yield per plant and grain protein content at the three nitrogen level. The average degree of dominance $(\mathrm{H} 1 / \mathrm{D})^{1 / 2}$ were found to be nearly equal unity for days to heading and 1000 grain weight at low nitrogen fertilization indicating that these characters were controlled by compelet dominance. The proportion of genes with positive and negative effects in the parents as indicated by $\mathrm{H} 2 / 4 \mathrm{H} 1$ were lese than its maximum value $(0.25)$ at the three nitrogen fertilization levels for days to heading, grain filling period, plant height, number of spikes/plant and grain protein content\% suggesting asymmetrical distribution of positive and negative alleles among the parental population. While, it was near to its maximum value $(0.25)$ for 1000 -grain weight and grain yield/plant at low and medium $\mathrm{N}$ fertilization levels, days to maturity and number of grains/spike at $75 \mathrm{~kg} . \mathrm{N} . / \mathrm{fad}$. indicating equal distribution of positive and negative alleles. Estimates of the ratio of dominant to recessive alleles in the parents $\mathrm{KD} / \mathrm{KR}$ were more than unity for most of the studied characters revealing more frequency of dominant alleles. The heritability estimates ranged from $7.9 \%$ for grain filling period at medium $\mathrm{N}$ fertilization to $69.5 \%$ for 1000 -grain weight in the third nitrogen level. Low heritability estimates were detected for grain filling period, main spike length, grain yield/plant and grain protein content\% at the three nitrogen levels 
indicating that most of the genetic variance may be due to non-additive genetic effect and was a fleeted by environmental factors, hereby selection should be delayed to later generations.

Keywords: Bread wheat, Nitrogen fertilization and genetic parameters.

\section{INTRODUCTION}

Wheat (Triticum aestivum L.) is the most important crop in terms of area and production because it is a staple food for more than one third of the world population. In Egypt, wheat is the main winter cereal crop. It used as a staple grain food for urban and rural societies and as a major source of straw for animal feeding. The inheritance of grain yield per plant in an $8 \times 8$ diallel crosses population of bread wheat was studied by Dere and Yildirim (2006).

They found that dominance variance component $\left(\widehat{H}_{1}\right)$ was significant for grain yield per plant. Dominance variance component $\left(h_{2}\right)$ and corrected dominance variance component $\left(\widehat{\mathrm{H}}_{2}\right)$ were significant for plant height and grain yield per plant. Using six generations model Dawwam et al.(2007) studied the genetical behavior of some quantitative characters in bread wheat and found that additive gene effects (a) were significant for plant height, number of grains per main culm ear, grains per ear, 1000-grain weight and grain yield per plant. Okan (2009) studied six experimental lines and one commercial wheat cultivar from diverse backgrounds using a half diallel and noted that spike length was determined by additive gene effect, while number of spikelets spike was controled by non-additive genes. Number of kernels per spike, 1000- kernel weight and yield per plant were affected by both additive and dominant genes. Heritability and gene action of yield and yield components were estimated in a GoliaxCumhuriyet 75 cross using generation mean analysis by Erkul et al.(2010). They found that additivedominance model was valid for spike length, number of spikelets per spike, 1000-kernel weight, fertile tiller number, and grain yield. Heritability estimates and genetic advances were low for number of kernels per spike, 1000-kernel weight and grain yield; medium for spike length, number of kernels per spikelet; high for number of spikelet per spike, spike yield and fertile tiller number. Performance of eight bread wheat (Triticum aestivum L.) were evaluated under three diverse environments (early, normal and late sown conditions) through an $8 \times 8$ diallel cross by Ahmad et al.(2011). They found that the dominance gene effects were larger in magnitude than the additive ones, resulting in average degree of dominance $(\hat{\mathrm{H}} 1 / \widehat{\mathrm{D}})^{1 / 2}$ more than unity in both generations. $F_{1}$ progenies of $7 \times 7$ diallel crosses comprising four high temperatures tolerant and three susceptible spring wheat parental genotypes were evaluated under normal and heat stress conditions by Irshad et al. (2012) They found that analysis of variance under both conditions indicated additive gene action with partial dominance was responsible for inhentance of days to heading, plant height, spikes/plant, spikelets/spike and grain 
yield/plant suggesting that these traits might be useful for the development of terminal heat tolerant varieties by modified pedigree selection.

The increase in grain yield with increasing $\mathrm{N}$-levels may be due to the improved growth which may account for the superiority of yield components and grain yield. The variation of agronomic management practices such as nitrogen fertilizer, seeding rates, sowing dates, irrigation and pest contoral influenced grain yield and yield components.

\section{MATERIALS AND METHODS}

The experiment was carried out at Tag EL-Ezz - Agricultural Research Station (Dakahliea Governorate), Agriculture Research Center, Egypt, during the two successive growing seasons 2010/2011 and 2011/2012. Six wheat cultivars of wide divergent origins were used to establish the experimental materials for this investigation and would be mentioned in the text as $P_{1}, P_{2}$, $P_{3}, P_{4}, P_{5}$, and $P_{6}$. The name, pedigree and origin of these cultivars are presented in Table 1.

Table 1. Name, pedigree and source of the studied bread wheat genotypes.

\begin{tabular}{|c|c|c|c|}
\hline Name & & Pedigree & Origin \\
\hline Misr 1 & $\left(P_{1}\right)$ & $\begin{array}{c}\text { OASIS/SKAUZ//4*BCN/3/2*PASTOR. } \\
\text { CM5500Y018881T-050M-030Y-030M-030WGY-33M-0Y-0S. }\end{array}$ & CIMMYT \\
\hline Giza 168 & $\left(\mathrm{P}_{2}\right)$ & $\begin{array}{c}\text { MRL/BUC//SERI. } \\
\text { CM 93046-8 M-OY-OM-2Y-OB-OGZ. }\end{array}$ & Egypt \\
\hline Shandaweel 1 & $\left(P_{3}\right)$ & $\begin{array}{c}\text { SITE/MO/4/NAC/TH.AC//3*PVN/3/MIRLO/BUC. } \\
\text { CM5593B005675-72Y-010M-010Y-010M-3Y-0M-0HTY-0SH. }\end{array}$ & CIMMYT \\
\hline Gemmeiza 9 & $\left(P_{4}\right)$ & $\begin{array}{l}\text { ALD“S"/HUAC"S"//CMH74A.630/Sx. } \\
\text { CGM 4583 -5GM-1 1GM- OGM }\end{array}$ & Egypt \\
\hline Sids 1 & $\left(P_{5}\right)$ & $\begin{array}{l}\text { HD2172/PAVON“S”//1158.57/MAYA74“S”. } \\
\text { SD46 -4SD-2SD-1SD-0SD. }\end{array}$ & Egypt \\
\hline Sakha 94 & (P6) & $\begin{array}{l}\text { OPATA /RAYON//KAUZ. } \\
\text { CMBW90Y3180-0TOPM-3Y-010M-010M-010Y-10M-015Y-0Y- } \\
\text { 0AP-0S. }\end{array}$ & CIMMYT \\
\hline
\end{tabular}

Experimental design and cultural practices:

A diallel crosses mating disign was carried out among the six parents in 2010/2011 growing season at Kafr El-hamam Agric. Res. Station. The parental varieties and their possible 15 crosses were sown in 2011/2012 growing season in Tag El-Ezz Agric. Res. Station under three nitrogen fertilization levels, which would be mentioned in the text as, 25 (low level), 50 (medium level) and 75 (normal level) kg.N./fed., in three adjacent experiments, respectively. Each experiment included the six parents and their 15 possible $F_{1}$ hybrids, which were sown on 21st November at Tag El-ezz location in a randomized complete block design with three replications per each experiment.

The experimental plot consisted of three rows 3 meters long with 30 $\mathrm{cm}$. between rows, plants within rows were $10 \mathrm{~cm}$. apart allowing a total of 30 plants /row in order to minimize border effects the middle row was planted by the $F_{1}$ hybrid while the outer two rows were planted by its two parents one row for each. Data were recorded on an individual plants for days to heading, days to maturity, grain filling period, plant height, main spike length number of spikes/plant, number of grains/spike, 1000-grain weight, grain yield/plant and grain protein content\%. Diallel analysis procedures as outlined by Hayman 
(1954 $a$ and b) and Mather and Jinks (1971) was used to estimate the relative magnitude of the genetic components of variance in additive to obtain information on the genetic mechanisms of the studied characters.

\section{RESULTS AND DISCUSSION}

\section{1- Analysis of variance:}

Data presented in Tables 2 showed that the mean squares due to wheat genotypes, parental cultivars and $F_{1}$ crosses were highly significant for all the studied characters under the three nitrogen levels providing evidence for the presence of sufficient amount of genetic variability adequate for further biometrical assessments. Parents versus crosses mean squares as an indication to average heterosis were found to be highly significant for the studied characters with two exceptions. Analysis of variance for the studied characters showed highly significant mean squares for nitrogen fertilization indicating overall differences among the three nitrogen fertilization levels. Genotypes $\times \mathrm{N}$ fertilization interactions were found to be highly significant, indicating that wheat materials behaved differently from one nitrogen level to another. In this connection highly significant differences between wheat genotypes, for yield and its contributing traits were also observed by Muhammad Akbar et al (2010), Singh and Sharma (2012), Mohammad Reza et al (2012), Rizkalla et al (2012), Mohammad Reza et al (2013) and Farshadfar et al (2013).

\section{2- Mean performance:}

The mean performances of the six parental wheat genotypes and their 15 hybrids are presented in Tables 3 . The most promising genotypes were $\mathrm{P}_{3}$ (Shandaweel1) and $\mathrm{P}_{6}$ (Sakha94) for early heading and maturity, $P_{2}$ (Giza168) and $P_{5}\left(\right.$ Sids1) for plant height, $P_{3}($ Shandaweel1) for longer main spike length, $P_{6}$ (Sakha94) and $P_{4}($ Gemmeiza9) for more number of spikes/plant, $\mathrm{P}_{3}($ Shandaweel1) for higher number of grains/spike and 1000 grain weight, $\mathrm{P}_{4}\left(\right.$ Gemmeiza9) for high grain yield/plant and $\mathrm{P}_{3}$ (Shandaweel1) had the highest grain protein content. Tables 3 showed that the hybrids: $\left(P_{4} \times P_{6}\right)$ gave performance for earliness and number of spikes/plant, $\left(P_{5} \times P_{6}\right)$ for longer main spike length, $\left(\mathrm{P}_{1} \times \mathrm{P}_{5}\right)$ was the shortest cross in plant height while $\left(P_{5} \times P_{6}\right)$ gave the tallest plant height, $\left(P_{3} \times P_{4}\right)$ for heavier 1000-grain weight, $\left(\mathrm{P}_{1} \times \mathrm{P}_{4}\right)$ gave the highest grain protein content. The maximum value for number of grains /spike and grain yield /plant was obtained by the hybrid $\left(\mathrm{P}_{1} \times \mathrm{P}_{5}\right)$.

\section{3- Genetic components of variance and heritability under three nitrogen} fertilization:

The genetic parameters for all traits under the three nitrogen levels are presented in Tables 4. Data showed that the additive variances (D) were significant for all the studied traits except grain filling period and number of grains per spike under three nitrogen fertilization levels, plant height and number of spikes per plant at $75 \mathrm{~kg} \mathrm{~N} / \mathrm{fed}$., main spike length at $25 \mathrm{~kg} \mathrm{~N} / \mathrm{fed}$. and grain yield/ plant at both 50 and $75 \mathrm{~kg} \mathrm{~N} / \mathrm{fed}$. These results indicated the importance of the additive gene effects in the inheritance of these traits under 
the three nitrogen levels. These results are in agreement with those obtained by Erkul et al. (2010) and Ahmad et al. (2011).

Significant values for the dominance components $(\mathrm{H} 1)$ and $(\mathrm{H} 2)$ were obtained for all traits under the three nitrogen levels except grain filling period at 50 and $75 \mathrm{~kg} \mathrm{~N} / \mathrm{fed}$. Values of $(\mathrm{H} 1)$ were higher in magnitude than their respective (D) ones for all traits under the three nitrogen levels, except 1000grain weight at $25 \mathrm{~kg} \mathrm{~N} / \mathrm{fed}$. These results indicated that non-additive type of gene action was the most prevalent in the genetic component for these traits. Similar results were previously obtained by Bakhsh et al. (2003), Bayoumi (2004), Dere and Yildirim (2006), Dawwam et al. (2007), Okan (2009), Ullah et al. (2010) and Ahmad et al. (2011).

Theoretically (H2) should be equal to or less than (H1)(Hayman, 1954b ). In this study the values of $(\mathrm{H} 2)$ were smaller than that of $(\mathrm{H} 1)$ for all traits under the three nitrogen levels. This result indicated that the positive and negative alleles frequencies at the loci for the previous cases in question are not equal in preparation in the parents. The overall dominance effects of heterozygous loci $\left(h^{2}\right)$ were computed. Significant $h^{2}$ values were detected for all traits studied at the three nitrogen levels, except grain filling period, number of spikes per plant number of grains per spike and grain yield per plant at the three nitrogen level; days to heading, plant height and 1000-grain weight at low nitrogen level, grain protein content \% at normal nitrogen level. Similar results were previously obtained by Singh and Sharma(2012).

The effect of dominance due to heterozygousity was of unidirectional appreciable causing heterotic effect. Similar results were previously obtained by Dere and Yildirim (2006) and Okan (2009).

The covariance of additive and dominance $(F)$ was not significant for days to maturity, grain filling period, plant height, number of spikes per plant, number of grains per spike, 1000-grain weight and grain yield per plant under the three levels of nitrogen, days to heading at medium and normal nitrogen levels, main spike length at low nitrogen level and grain protein content \% at low and normal nitrogen levels indicating an excess of recessive overdominance allelels. On the other hand, the other cases were found to be positive and significant, showing that the dominant alleles were more frequent than the recessive ones, irrespective of weather or not the dominant alleles have increasing or decreasing effects Mather and Jinks (1971). These findings were in the same line with those reached by Wagoire et al. (1998), Hamada (2003) and Nazeer et al. (2004). The relative size of (D) and (H1) estimated as $(\mathrm{H} 1 / \mathrm{D})^{1 / 2}$ could be used as weight measure of the average degree of dominance at each locus which showed the presence of over dominance for all traits under the three nitrogen levels, except days to heading and 1000-grain weight at the first nitrogen level. The dominance ratio $(\mathrm{H} 1 / \mathrm{D})^{1 / 2}$ for the last trait was found to be nearly equal unity indicating that this trait was controlled by compelet dominance. These results suggested that crossing and selection (pedigree method) could be useful to make use of most non-additive gene effects which would be isolated in the transgressive segregation. The importance of non-additive gene effects in the genetic control of the studied traits was also reported by Dere and Yildirim (2006) and Seleem and Koumber (2011). 
Gebrel,E.M.A.H. et al.

2 
J.Agric.Chem.and Biotechn., Mansoura Univ.Vol. 5 (8), August, 2014 2 
Gebrel,E.M.A.H. et al.

3 
J.Agric.Chem.and Biotechn., Mansoura Univ.Vol. 5 (8), August, 2014 4 
The two dominant components $(\mathrm{H} 1$ and $\mathrm{H} 2)$, generally, were significant. They greatly differed in their magnitudes, suggesting that positive and negative alleles were not equally distributed in the parental genotypes. These results are supported by the ratio of $(\mathrm{H} 2 / 4 \mathrm{H} 1)$. When positive and negative genes are equally distributed in the parental varieties, the proportion $(\mathrm{H} 2 / 4 \mathrm{H} 1)$ is expected to be 0.25 . The estimated values of $(\mathrm{H} 2 / 4 \mathrm{H} 1)$ in this study were found to be close to this value for most traits. The estimated values of $(\mathrm{H} 2 / 4 \mathrm{H} 1)$ however, were found to be less than $(0.25)$ for number of spikes/plant at medium and normal nitrogen levels in addition to grain protein content at three nitrogen levels, indicating that positive and negative alleles were not equally distributed among the parents for these traits. Similar results were previously obtained by Koumber and El-Gammaal (2012).

The proportion of dominance to recessive genes in the parents were more than unity $(K D / K R>1)$ for all traits under three nitrogen levels, except number of grains /spike at medium nitrogen level and 1000-grain weight under the normal level. These data showed that the proportion of dominant alleles are greater in the parents than the recessive ones for these traits under the three nitrogen levels, while the recessive genes are in excess for the remaining traits compared to the dominant ones. The correlation coefficient value between parental mean $(\mathrm{Yr})$ and $(\mathrm{wr}+\mathrm{vr})$ for each array was positive for days to heading at the first nitrogen level, grain filling period and number of spikes/plant under the second and the third $\mathrm{N}$ levels, plant height and number of grains per spike at 25, 50 and $75 \mathrm{~kg} \mathrm{~N} / \mathrm{fed}, 1000$-grain weight and grain protein content \% at the third nitrogen level and grain yield per plant under the second $\mathrm{N}$ level. These indicated that decreases genes were dominant over increase ones. For other traits studied, low correlation values were obtained where $(r)$ could not be fruitful in getting any idea about the direction of dominance. Such low value of correlation coefficient might be due to the presence of epistasis and to additively of most genes involving the system for these traits. Also, it might reveal that high performance for such traits was controlled by dominant and recessive genes as well.

\section{Heritability values:}

Information on heritability estimates are useful to formulate the expected genetic advance from selection through generations in wheat breeding programs.

The ratio of additive genetic variance to total genetic variance is an estimation of heritability in narrow sense which was relatively high for days to heading at the first nitrogen level, number of spikes /plant at second level and 1000 grain weight under 25, 50, $70 \mathrm{~kg} \mathrm{~N} / \mathrm{fed}$., Thus, for these traits selection based on phenotype could be effective to improve and develop wheat genotypes concerning these traits under these conditions. High value of narrow sense heritability was also reported by Kheiralla et al. (1993) and Hamada (2003).

Heritability estimates in narrow sense for all traits under three nitrogen levels are given in Tables 4 . The heritability estimates ranged from 0.079 for grain filling period at the second nitrogen level to 0.695 for 1000 - grain 
weight at the third nitrogen level. Moderate to low heritability estimates were given for the other traits under different nitrogen levels, indicating that most of the genetic variance may be due to non-additive genetic effect. These findings support the previous results of genetic components in which $\mathrm{H}_{1}$ estimates were found to have great role in these traits. Therefore, the bulk method program for most traits might be quite promising. Similar results were reported by Al-Kaddoussi (1996), Hamada (2003), Talebi and Fayyaz (2012) and Farshadfar et al (2013) .

\section{REFERENCES}

Ahmad. F.; S. Khan1; S. Q. Ahmad; H. Khan; A. Khan and F. Muhammad (2011). Genetic analysis of some quantitative traits in bread wheat across environments. African Journal of Agricultural Research. 6(3) 686-692.

AL-Kaddoussi, A. R.(1996). Inheritance of some growth and yield characters in wheat (Triticum aestivum L.) Zagazig J. Agric.Res., 17(3) 17-25.

Bakhsh, A.; A. Hussain and A. S. Khan (2003). Genetic studies of plant height, yield and its components in bread wheat . Sarhad J. Agric., 19 (4) :529-534.

Bayoumi, T. Y. (2004). Diallel cross analysis for bread wheat under stress and normal irrigation treatments. Zagazig J. Agric. Res., 31 (2) 435 455.

Dawwam, H. A.; F. A. Hendawy and Marwa. M. El-Nahas (2007). Genetical behavriour of some quantitative characters in bread wheat (Triticum aestivum L.). Minufiya J. Agric. Res., 32 (4): 1037 - 1054.

Dere, S. and M. B. Yildirim (2006). Inheritance of grain yield per plant, flag leaf width and length in an $8 \times 8$ diallel cross population of bread wheat (Triticum aestivum L.). Turk. J. Agric., 30: $339-345$.

Erkul, A.; A. Unay and C. Konak (2010). Inheritance of yield and yield components in a bread wheat (Triticum aestivum L.) cross. Turkish Journal of Field Crops. 15(2): 137-140.

Farshadfar, E.; Rafiee, F. and A. Yghotipoor, (2013). Comparison of the efficiency among half diallel methods in the genetic analysis of bread wheat (Triticum aestivum L.) under drought stress condition. Annals of Biological Research; 3: 3, 1607-1622.

Hamada, A. A. (2003). Heterosis and gene action of yield and its components and some growth traits in an eight parents diallel cross of bread wheat under three sowing dates. Minufiya J. Agric. Res., 28 (3): 787 - 819.

Hayman. B.I. (1954a). The analysis of variance of diallel tables. Biometerics. 10: $235-244$.

Hayman. B.I. (1954b). The theory and analysis of diallel crosses. Genetics. 39: 789-809.

Irshad, M.; I. Khaliq.;1 A. S. Khan1 and A. Ali (2012). Genetic studies for some agronomic traits in spring wheat under heat stress. Pak. J. Agri. Sci., Vol. 49(1), 11-20. 
Kheiralla, K.A; M.M. El-Defrawy and T.H. i. Sherif (1993). Genetic analysis of grain yield, biomass and harvest index in wheat under drought stress and normally moisture conditions. Assiut J. Agric.Sci., 24(3) 163-183.

Koumber,R.M. and A.A. El-Gammaal, (2012). Inheritance and gene action for yield and its attributes in three bread wheat crosses (Triticum aestivum L.). World Journal of Agricultural Sciences; 8: 2, 156-162. 18.

Mather, K. and J.L. Jinks. (1971). Biometrical Genetics (2nd edition) 255-287. Chapman and Hall, Ltd. London.

Mather, K. and J. L. Jinks (1982). Biometrical Genetics. (3rd edition), Chapman and Hall, London.

Mohammad Reza, N. R.; Mihdzar Abdul Kadir; Rafii, M. Y.; Jaafar, H. Z. E. and Mahmoud Danaee (2013). Gene action for physiological parameters and use of relative water content (RWC) for selection of tolerant and high yield genotypes in $\mathrm{F}<\mathrm{sub}>2</$ sub $>$ population of wheat. Australian Journal of Crop Science; 7: 3, 407-413. 35.

Mohammad Reza, N. R.; Kadir, M. A. and M. R. Yusop, (2012). Genetic behaviour for plant capacity to produce chlorophyll in wheat (Triticum aestivum L.) under drought stress. Australian Journal of Crop Science; 6: 3, 415-420. 30.

Muhammad Akbar; Javed Anwar; Makhdoom Hussain; lqbal, M. M. and Waseem Sabir.(2010). Heterosis and heterobeltiosis for grain yield improvement in bread wheat. Journal of Agricultural Research (Lahore); 48: 1, 15-23. 16.

Nazeer, A.W.; M. Safeer-ul-Hassan, and Zahid-Akram (2004). Genetic architecture of some agronomic traits in diallel cross of bread wheat. Pakistan-J.I.of-Biol. Sci., 7(8): 1340-1342.

Okan, S. (2009). Identification of breeding potential for grain yield and its component traits of common wheat varieties in the east Mediterranean. Agrociencia. 43: 707-716.

Rizkalla, A. A.; Hussien, B. A.; Al-Ansary, A. M. F.; Nasseef, J. E. and M. H. A.Hussein, (2012). Combining ability and heterosis relative to RAPD marker in cultivated and newly hexaploid wheat varieties. Australian Journal of Basic and Applied Sciences; 6: 5, 215-224. 46.

Seleem, S.A. and R.M.A. Koumber (2011). Estimation of combining ability and gene action in the F1 and F2 generations in some breed wheat crosses. Minufiya J. Agric. Res., 36 (6):1627-1648.

Singh, M. K. and P. K. Sharma, (2012). Relationship of heterosis for protein content with yield component traits under normal/heat-stress environment in spring wheat. Crop Improvement; 39: 1, 8-17. 27.

Talebi, R. and F. Fayyaz, (2012) Estimation of heritability and genetic parameters associated with agronomic traits of bread wheat (Triticum aestivum L.) under two constructing water regimes. Journal of Applied Biological Sciences; 6: 3, 35-39. 24.

Ullah, S.; A.S. Khan; A. Raza and S. Sadique (2010). Gene Action analysis of yield and yield related traits in spring wheat (Triticum aestivum L.). Int. J. Agric. Biol., 12: 125-128. 
Wagoire W.W.; O.Stolen and R. Ortiz (1998). Combining ability analysis in bread wheat adapted to the East African highlands. Wheat Information - Service., 87:39 - 41.

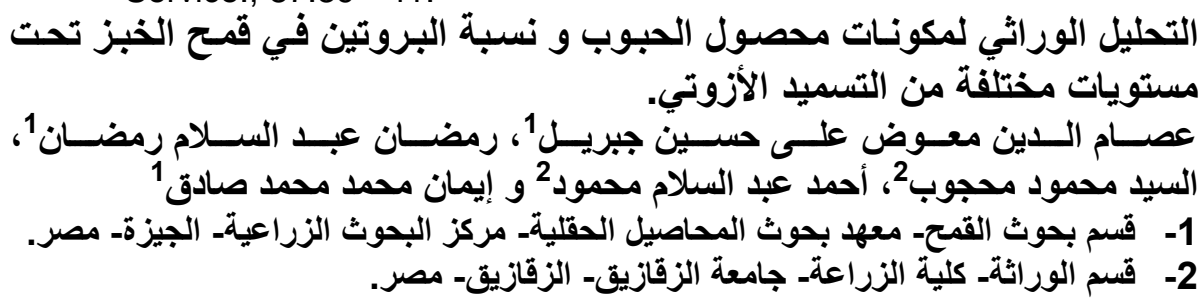

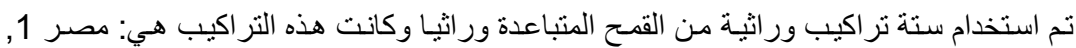

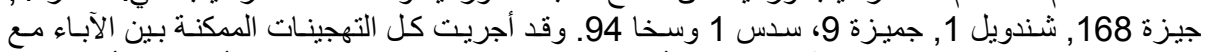

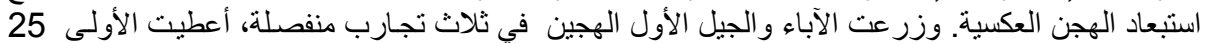

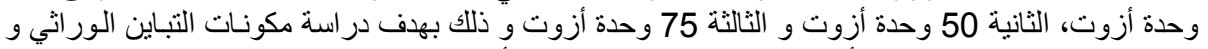

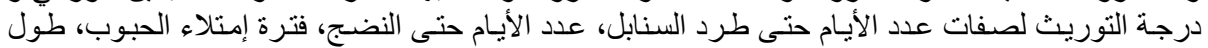

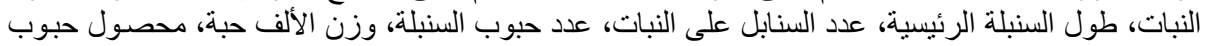
النبات و محتوى الحبوب من البروتين. وقد حللت النتائج تبعا لها يمان 1954 و و قوة الهجين بطريقة ماذر و

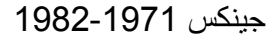

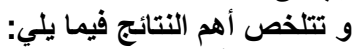

أدى استخدام المستوى المنخفض من التسميد النيتروجيني (25 وحدة أزوت/فدان) إلى انخفاض في التئي

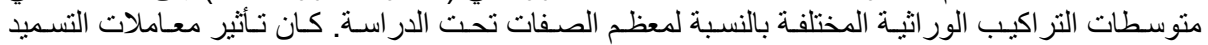

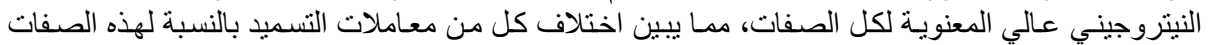

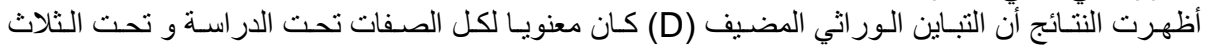

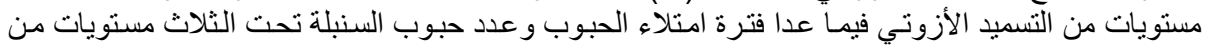

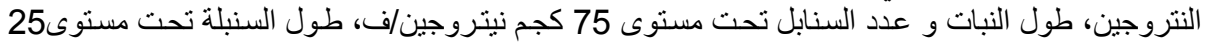

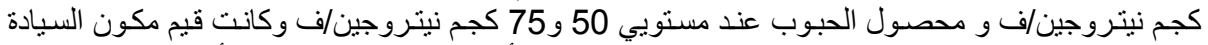

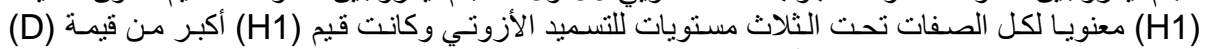

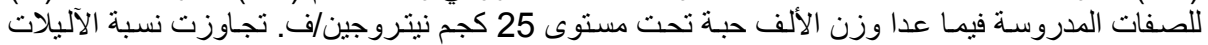

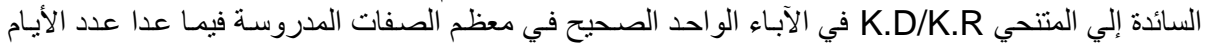

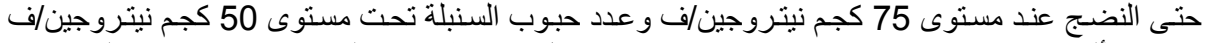

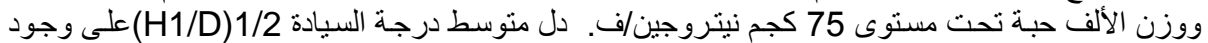

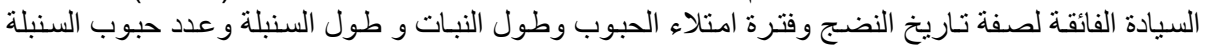

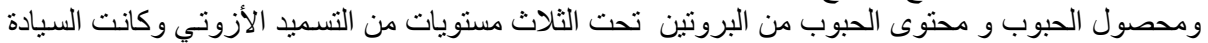

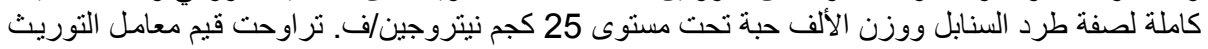

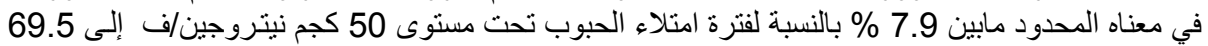

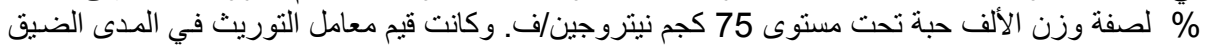

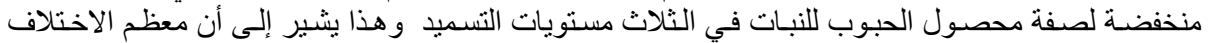

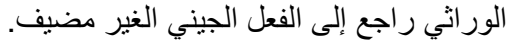



Table 2: Mean square estimates of ordinary analysis for all traits studied under the three different nitrogen fertilization levels and their combined analysis.

\begin{tabular}{|c|c|c|c|c|c|c|c|c|c|c|c|c|c|c|}
\hline \multirow[b]{2}{*}{ Source of variation } & \multirow[b]{2}{*}{ d.f } & \multirow{2}{*}{$\begin{array}{c}\text { d.f } \\
\text { Comb. }\end{array}$} & \multicolumn{4}{|c|}{ Days to heading (day) } & \multicolumn{4}{|c|}{ Days to maturity(day) } & \multicolumn{4}{|c|}{ Grain filling period(day) } \\
\hline & & & $\begin{array}{c}25 \\
\mathrm{~kg} / \mathrm{fed}\end{array}$ & $\begin{array}{c}50 \\
\mathrm{~kg} / \mathrm{fed}\end{array}$ & $\begin{array}{c}75 \\
\mathrm{~kg} / \mathrm{fed}\end{array}$ & Comb. & $\begin{array}{c}25 \\
\mathrm{~kg} / \mathrm{fed}\end{array}$ & $\begin{array}{c}50 \\
\mathrm{~kg} / \mathrm{fed}\end{array}$ & $\begin{array}{c}75 \\
\mathrm{~kg} / \mathrm{fed}\end{array}$ & Comb. & $\begin{array}{c}25 \\
\mathrm{~kg} / \mathrm{fed}\end{array}$ & $\begin{array}{c}50 \\
\mathrm{~kg} / \mathrm{fed}\end{array}$ & $\begin{array}{c}75 \\
\mathrm{~kg} / \mathrm{fed}\end{array}$ & Comb. \\
\hline N.levels & 2 & 6 & 0.52 & 0.64 & 0.66 & 0.61 & 0.51 & 0.43 & 0.26 & 0.40 & 0.01 & 0.03 & 0.05 & 0.03 \\
\hline Genot & 20 & 20 & $14.42^{* *}$ & $42.63^{\star *}$ & $49.01^{\star *}$ & $83.13^{* *}$ & $22.26^{\star *}$ & $16.63^{\star *}$ & $16.32^{\star *}$ & $49.47^{* *}$ & $15.36^{* *}$ & $16.29^{\star \star}$ & $18.54^{\star *}$ & $38.85^{\star *}$ \\
\hline Parents & 5 & 5 & $30.38^{\star \star}$ & $41.66^{\star \star}$ & $47.09^{\star \star}$ & $114.90^{* *}$ & $24.72^{* *}$ & $15.99^{\star \star}$ & $13.74^{\star \star}$ & $47.02^{* *}$ & $12.03^{* *}$ & $13.37^{* *}$ & $14.06^{\star *}$ & $36.46^{\star \star}$ \\
\hline Crosses & 14 & 14 & $9.10^{* \star}$ & $19.96^{* \star}$ & $19.30^{* *}$ & $31.82^{* \star}$ & $14.70^{* *}$ & $9.82^{* *}$ & $9.79^{* *}$ & $28.75^{\star \star}$ & $14.15^{* \star}$ & $15.73^{\star \star}$ & $16.87^{* \star}$ & $41.23^{* *}$ \\
\hline Par. Vs. crosses & 1 & 1 & $9.12^{\star \star}$ & $364.89^{\star \star}$ & $474.62^{* *}$ & $642.61^{* *}$ & $115.83^{* \star}$ & $115.29^{\star \star}$ & $120.59^{\star \star}$ & $351.67^{* *}$ & $49.07^{* *}$ & $38.64^{* *}$ & $64.45^{* *}$ & $17.47^{\star \star}$ \\
\hline Genotypes $\times N$ & - & $\overline{11}$ & - & - & - & $11.47^{\star *}$ & - & - & - & $2.87^{\star *}$ & - & - & - & $5.67^{\star \star}$ \\
\hline Parents & - & 10 & - & - & - & $2.11^{* *}$ & - & 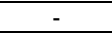 & - & $3.72^{* \star}$ & - & - & - & $1.49^{* *}$ \\
\hline Crosses $x$ & - & 28 & - & - & - & $8.27^{\star \star}$ & - & - & - & $2.78^{\star \star}$ & - & - & - & $2.76^{\star \star}$ \\
\hline Par.Vs.crosses $\times$ N.levels & 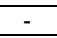 & 2 & - & - & - & $103.01^{* *}$ & - & - & - & 0.02 & - & - & - & $67.35^{\star \star}$ \\
\hline Error & 40 & 120 & 0.64 & 1.09 & 0.72 & 0.82 & 1.52 & 1.20 & 0.43 & 1.05 & & 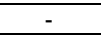 & - & 0.05 \\
\hline
\end{tabular}

\section{Table 2: Cont.}

\begin{tabular}{|c|c|c|c|c|c|c|c|c|c|c|c|c|c|c|}
\hline \multirow[b]{2}{*}{ Source of variation } & \multirow[b]{2}{*}{ d.f } & \multirow[b]{2}{*}{$\begin{array}{c}\text { d.f } \\
\text { Comb. }\end{array}$} & \multicolumn{4}{|c|}{ Plant height (cm) } & \multicolumn{4}{|c|}{ Main spike length $(\mathrm{cm})$} & \multicolumn{4}{|c|}{ Number of spike/plant } \\
\hline & & & \begin{tabular}{c|}
25 \\
$\mathrm{~kg} / \mathrm{fed}$
\end{tabular} & $\begin{array}{c}50 \\
\mathrm{~kg} / \mathrm{fed}\end{array}$ & $\begin{array}{c}75 \\
\mathrm{~kg} / \mathrm{fed}\end{array}$ & Comb. & \begin{tabular}{|c|}
25 \\
$\mathrm{~kg} / \mathrm{fed}$
\end{tabular} & $\begin{array}{c}50 \\
\mathrm{~kg} / \mathrm{fed}\end{array}$ & $\begin{array}{c}75 \\
\mathrm{~kg} / \mathrm{fed}\end{array}$ & Comb. & $\begin{array}{c}25 \\
\mathrm{~kg} / \mathrm{fed}\end{array}$ & $\begin{array}{c}50 \\
\mathrm{~kg} / \mathrm{fed}\end{array}$ & $\begin{array}{c}75 \\
\mathrm{~kg} / \mathrm{fed}\end{array}$ & Comb. \\
\hline Reps/N.levels & 2 & 6 & 0.80 & 0.26 & 0.73 & 0.60 & 0.63 & 0.72 & 0.18 & 0.51 & 0.04 & 0.25 & 0.15 & 0.14 \\
\hline Genotypes & 20 & 20 & $51.89^{\star \star}$ & $58.12^{\star \star}$ & $74.91^{\star \star}$ & $174.83^{* \star}$ & $2.73^{\star \star}$ & $2.85^{\star *}$ & $3.96^{* \star}$ & $7.38^{\star \star}$ & $11.86^{* \star}$ & $5.18^{\star \star}$ & $20.17^{\star \star}$ & $26.35^{\star *}$ \\
\hline Parents & 5 & 5 & $57.91^{* *}$ & $84.01^{* *}$ & $56.87^{\star *}$ & $184.11^{* *}$ & $2.43^{* *}$ & $4.40^{\star \star}$ & $5.23^{* *}$ & $8.77^{* *}$ & $14.22^{* \star}$ & $7.09^{* *}$ & $9.87^{* *}$ & $26.88^{\star \star}$ \\
\hline Crosses & 14 & 14 & $50.12^{\star *}$ & $45.27^{\star *}$ & $68.37^{* \star}$ & $157.68^{* \star}$ & $2.66^{\star \star}$ & $1.72^{*}$ & $1.53^{* *}$ & $4.42^{* \star}$ & $10.90^{* \star}$ & $4.82^{* \star}$ & $25.16^{* *}$ & $27.22^{* *}$ \\
\hline Par. Vs. crosses & 1 & 1 & $46.45^{\star \star}$ & $108.56^{* \star}$ & $256.62^{* \star}$ & $368.60^{* \star}$ & $5.17^{\star \star}$ & $10.87^{\star \star}$ & $31.66^{\star *}$ & $41.78^{\star *}$ & $13.36^{\star \star}$ & 0.69 & $1.91^{*}$ & $11.48^{\star \star}$ \\
\hline Genotypes×N.levels & - & 40 & - & - & - & $5.04^{\star \star}$ & - & - & - & $1.08^{\star \star}$ & - & - & - & $5.43^{\star \star}$ \\
\hline Parents $\times$ N.levels & - & 10 & - & - & - & $7.34^{\star \star}$ & - & - & - & $1.64^{\star \star}$ & - & - & - & $2.15^{\star \star}$ \\
\hline Crosses $\times$ N.levels & 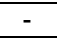 & 28 & - & - & - & $3.04^{* *}$ & - & - & - & 0.75 & - & - & - & $6.83^{\star \star}$ \\
\hline Par.Vs.crosses $\times$ N.levels & 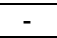 & 2 & - & - & - & $21.51^{\star \star}$ & - & - & - & $2.95^{\star \star}$ & - & - & - & 2.24 \\
\hline Error & 40 & 120 & 1.40 & 0.41 & 0.90 & 0.90 & 0.59 & 0.77 & 0.29 & 0.55 & 1.46 & 0.52 & 0.39 & 0.79 \\
\hline
\end{tabular}

${ }^{*}$ and ${ }^{* *}=$ Significant at 0.05 and 0.01 levels of probability, respectively

Comb. = Combined 
Gebrel,E.M.A.H. et al.

-2 - 
J.Agric.Chem.and Biotechn., Mansoura Univ.Vol. 5 (8): 201 - 213, 2014

Table 2: Cont.

\begin{tabular}{|c|c|c|c|c|c|c|c|c|c|c|c|c|c|c|}
\hline \multirow[b]{2}{*}{ Source of variation } & \multirow[b]{2}{*}{ d.f } & \multirow[b]{2}{*}{$\begin{array}{c}\text { d.f } \\
\text { Comb. }\end{array}$} & \multicolumn{4}{|c|}{ Number of grain/ spike } & \multicolumn{4}{|c|}{ 1000-grain weight (gm) } & \multicolumn{4}{|c|}{ Grain yield / plant (gm) } \\
\hline & & & $\begin{array}{c}25 \\
\mathrm{~kg} / \mathrm{fed}\end{array}$ & $\begin{array}{c}50 \\
\mathrm{~kg} / \mathrm{fed}\end{array}$ & $\begin{array}{c}75 \\
\mathrm{~kg} / \mathrm{fed}\end{array}$ & Comb. & $\begin{array}{c}25 \\
\mathrm{~kg} / \mathrm{fed}\end{array}$ & $\begin{array}{c}50 \\
\mathrm{~kg} / \mathrm{fed}\end{array}$ & $\begin{array}{c}75 \\
\mathrm{~kg} / \mathrm{fed}\end{array}$ & Comb. & $\begin{array}{c}25 \\
\mathrm{~kg} / \mathrm{fed}\end{array}$ & $\begin{array}{c}50 \\
\mathrm{~kg} / \mathrm{fed}\end{array}$ & $\begin{array}{c}75 \\
\mathrm{~kg} / \mathrm{fed}\end{array}$ & Comb. \\
\hline Reps/N.levels & 2 & 6 & 0.61 & 0.20 & 0.10 & 0.30 & 0.26 & 0.20 & 0.14 & 0.20 & 0.24 & 0.72 & 0.19 & 0.38 \\
\hline Genotypes & 20 & 20 & $36.66^{\star \star}$ & $33.49^{\star *}$ & $120.59^{\star \star}$ & $133.62^{\star *}$ & $17.16^{\star \star}$ & $15.67^{\star \star}$ & $18.23^{\star *}$ & $48.13^{\star *}$ & $34.23^{* *}$ & $39.96^{\star *}$ & $66.85^{\star *}$ & $91.84^{\star \star}$ \\
\hline Parents & 5 & 5 & $18.85^{\star \star}$ & $9.07^{\star \star \star}$ & $42.08^{* *}$ & $55.80^{\star \star}$ & $28.54^{\star \star}$ & $20.83^{\star \star}$ & $23.61^{* \star}$ & $69.54^{\star \star}$ & $34.52^{* \star}$ & $20.55^{\star \star}$ & $33.53^{\star \star}$ & $32.46^{\star *}$ \\
\hline Crosses & 14 & 14 & $43.70^{\star \star}$ & $43.12^{\star \star}$ & $146.36^{* *}$ & $159.30^{\star \star}$ & $13.13^{\star \star}$ & $12.73^{\star \star}$ & $16.23^{\star \star}$ & $39.22^{\star \star}$ & $36.46^{* *}$ & $46.85^{\star \star}$ & $83.31^{\star \star}$ & $118.49^{\star \star}$ \\
\hline Par. Vs. crosses & 1 & 1 & $27.22^{\star *}$ & $20.86^{* *}$ & $152.34^{\star \star}$ & $163.22^{* *}$ & $16.71^{* \star}$ & $31.04^{\star *}$ & $19.40^{* *}$ & $65.92^{* *}$ & 1.62 & $40.52^{* *}$ & $3.01^{*}$ & $15.55^{\star *}$ \\
\hline Genotypes $\times$ N.levels & - & 40 & - & - & - & $28.56^{\star *}$ & - & - & - & $1.47^{\star *}$ & - & - & - & $24.60^{* *}$ \\
\hline Parents $\times$ N.levels & - & 10 & - & - & - & $7.10^{\star *}$ & - & - & - & $1.72^{\star \star}$ & - & - & - & $28.07^{\star *}$ \\
\hline Crosses $\times$ N.levels & - & 28 & - & - & - & $36.94^{\star *}$ & - & - & - & $1.43^{\star \star}$ & - & - & - & $24.06^{\star *}$ \\
\hline Par.Vs.crosses $\times$ N.levels & - & 2 & - & - & - & $18.61^{\star *}$ & - & 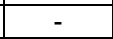 & 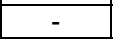 & 0.61 & - & - & - & $14.80^{\star \star}$ \\
\hline Error & 40 & 120 & 1.14 & 0.47 & 0.30 & 0.64 & 0.81 & 0.63 & 0.37 & 0.61 & 0.60 & 0.85 & 0.64 & 0.70 \\
\hline
\end{tabular}

Table 2: Cont.

\begin{tabular}{|c|c|c|c|c|c|c|}
\hline \multirow[b]{2}{*}{ Source of variation } & \multirow[b]{2}{*}{ d.f } & \multirow{2}{*}{$\begin{array}{c}\text { d.f } \\
\text { Comb. }\end{array}$} & \multicolumn{4}{|c|}{ Grain protein content (\%) } \\
\hline & & & $\begin{array}{c}25 \\
\mathrm{~kg} / \mathrm{fed}\end{array}$ & $\begin{array}{c}50 \\
\mathrm{~kg} / \mathrm{fed}\end{array}$ & $\begin{array}{c}75 \\
\mathrm{~kg} / \mathrm{fed}\end{array}$ & Comb. \\
\hline Reps/N.levels & 2 & 6 & 0.03 & 0.03 & 0.00 & 0.02 \\
\hline Genotypes & 20 & 20 & $2.05^{\star *}$ & $1.56^{\star *}$ & $1.59^{\star *}$ & $3.75^{\star \star}$ \\
\hline Parents & 5 & 5 & $3.03^{* *}$ & $2.89^{\star *}$ & $3.20^{\star *}$ & $6.75^{\star \star}$ \\
\hline Crosses & 14 & 14 & $1.42^{\star *}$ & $0.47^{* *}$ & $1.03^{\star *}$ & $1.84^{\star *}$ \\
\hline Par. Vs. crosses & 1 & 1 & $5.96^{\star *}$ & $10.00^{\star *}$ & $1.46^{* *}$ & $15.47^{* \star}$ \\
\hline Genotypes×N.levels & - & 40 & - & - & - & $0.72^{\star \star}$ \\
\hline Parents $\times$ N.levels & - & 10 & - & - & - & $1.19^{\star *}$ \\
\hline Crosses $\times$ N.levels & - & 28 & - & - & - & $0.54^{\star \star}$ \\
\hline Par.Vs.crosses $\times$ N.levels & - & 2 & - & - & - & 0.98 \\
\hline Error & 40 & 120 & 0.04 & 0.03 & 0.03 & 0.03 \\
\hline
\end{tabular}

Error

${ }^{*}$ and ${ }^{* *}=$ Significant at 0.05 and 0.01 levels of probability, respectively .

Comb. $=$ Combined 
Gebrel,E.M.A.H. et al.

- 2 - 
Table 4 : Estimates of genetic components of variation and their ratios for traits studied under the three different nitrogen fertilization levels.

\begin{tabular}{|c|c|c|c|c|c|c|c|c|c|c|c|c|c|c|c|}
\hline \multirow{2}{*}{$\begin{array}{r}\text { Genetic } \\
\text { component }\end{array}$} & \multicolumn{3}{|c|}{ Days to heading (day) } & \multicolumn{3}{|c|}{ Days to maturity(day) } & \multicolumn{3}{|c|}{ Grain filling period(day) } & \multicolumn{3}{|c|}{ Plant height $(\mathrm{cm})$} & \multicolumn{3}{|c|}{ Main spike length (cm) } \\
\hline & $\begin{array}{c}25 \\
\mathrm{kgN} / \mathrm{fed}\end{array}$ & $\begin{array}{c}50 \\
\mathrm{kgN} / \mathrm{fed}\end{array}$ & $\begin{array}{c}75 \\
\mathrm{kgN} / \mathrm{fed}\end{array}$ & $\begin{array}{c}25 \\
\mathrm{kgN} / \mathrm{fe} \\
\mathrm{d}\end{array}$ & \begin{tabular}{|c|}
50 \\
$\mathrm{~kg} / \mathrm{fed}$
\end{tabular} & $\begin{array}{c}75 \\
\mathrm{Kg} \\
\mathrm{N} / \mathrm{fed}\end{array}$ & $\begin{array}{c}25 \\
\mathrm{kgN} / \mathrm{fed}\end{array}$ & $\begin{array}{c}50 \\
\mathrm{kgN} / \mathrm{fed}\end{array}$ & $\begin{array}{c}75 \\
\mathrm{kgN} / \mathrm{fed}\end{array}$ & $\begin{array}{c}25 \\
\mathrm{kgN} / \mathrm{fe} \\
\mathrm{d}\end{array}$ & $\begin{array}{c}50 \\
\mathrm{~kg} / \mathrm{fed}\end{array}$ & $\begin{array}{c}75 \\
\mathrm{kgN} / \mathrm{fe} \\
\mathrm{d}\end{array}$ & $\begin{array}{c}25 \\
\mathrm{kgN} / \mathrm{fed}\end{array}$ & $\begin{array}{c}50 \\
\mathrm{kgN} / \mathrm{fe} \\
\mathrm{d}\end{array}$ & $\begin{array}{c}75 \\
\mathrm{kgN} / \mathrm{fed}\end{array}$ \\
\hline D & $\begin{array}{l}9.91^{\star *} \\
\pm 0.92\end{array}$ & $\begin{array}{l}13.53^{*} \\
\pm 6.60\end{array}$ & $\begin{array}{l}15.45^{*} \\
\pm 6.71\end{array}$ & $\begin{array}{l}7.75^{\star \star} \\
\pm 1.85\end{array}$ & $\begin{array}{l}4.94^{\star *} \\
\pm 1.23\end{array}$ & $\begin{array}{l}4.44^{\star \star} \\
\pm 0.56\end{array}$ & $\begin{array}{c}4.0002 \\
\pm 3.56\end{array}$ & $\begin{array}{c}4.43 \\
\pm 6.41 \\
\end{array}$ & $\begin{array}{c}4.67 \\
\pm 6.59 \\
\end{array}$ & \begin{tabular}{|c|}
$18.84^{*}$ \\
\pm 8.69 \\
\end{tabular} & $\begin{array}{c}27.86^{* *} \\
\pm 6.62 \\
\end{array}$ & \begin{tabular}{|c|}
18.65 \\
\pm 11.33 \\
\end{tabular} & $\begin{array}{c}0.61 \\
\pm 0.37\end{array}$ & $\begin{array}{l}1.21^{* *} \\
\pm 0.30\end{array}$ & $\begin{array}{l}1.64^{\star \star} \\
\pm 0.31\end{array}$ \\
\hline $\mathrm{F}$ & $\begin{array}{l}6.28^{\star *} \\
\pm 2.25 \\
\end{array}$ & \begin{tabular}{|c|}
16.14 \\
\pm 16.143 \\
\end{tabular} & \begin{tabular}{|c|}
15.13 \\
\pm 16.41 \\
\end{tabular} & $\begin{array}{c}3.78 \\
\pm 4.53 \\
\end{array}$ & $\begin{array}{c}2.04 \\
\pm 3.02 \\
\end{array}$ & $\begin{array}{r}-0.46 \\
\pm 1.38 \\
\end{array}$ & $\begin{array}{c}5.49 \\
\pm 8.71 \\
\end{array}$ & $\begin{array}{c}9.38 \\
\pm 15.66 \\
\end{array}$ & $\begin{array}{c}8.93 \\
\pm 16.11 \\
\end{array}$ & \begin{tabular}{|c|}
17.09 \\
\pm 21.23 \\
\end{tabular} & $\begin{array}{l}26.10^{* *} \\
\pm 16.17 \\
\end{array}$ & \begin{tabular}{|c|}
14.73 \\
\pm 27.69 \\
\end{tabular} & $\begin{array}{c}0.26 \\
\pm 0.91 \\
\end{array}$ & $\begin{array}{l}1.88^{*} \\
\pm 0.74 \\
\end{array}$ & $\begin{array}{l}1.56^{*} \\
\pm 0.75 \\
\end{array}$ \\
\hline $\mathrm{H} 1$ & $\begin{array}{l}9.14^{\star *} \\
\pm 2.34\end{array}$ & $\begin{array}{l}48.92^{\star *} \\
\pm 16.77\end{array}$ & $\begin{array}{l}52.57^{\star *} \\
\pm 17.05\end{array}$ & $\begin{array}{c}18.26^{\star *} \\
\pm 4.71\end{array}$ & $\begin{array}{c}13.18^{* *} \\
\pm 3.14\end{array}$ & $\begin{array}{c}11.12^{\star *} \\
\pm 1.43\end{array}$ & $\begin{array}{l}21.49^{*} \\
\pm 9.05\end{array}$ & $\begin{array}{c}28.45 \\
\pm 16.27\end{array}$ & $\begin{array}{c}30.10 \\
\pm 16.74 \\
\end{array}$ & $\begin{array}{l}61.41^{* *} \\
\pm 22.06\end{array}$ & $\begin{array}{l}64.71^{* *} \\
\pm 16.80\end{array}$ & $\begin{array}{l}91.78^{\star *} \\
\pm 28.77\end{array}$ & $\begin{array}{l}2.84^{\star *} \\
\pm 0.95\end{array}$ & $\begin{array}{l}3.47^{\star \star} \\
\pm 0.77\end{array}$ & $\begin{array}{l}3.57^{\star \star} \\
\pm 0.78\end{array}$ \\
\hline $\mathrm{H} 2$ & $\begin{array}{l}7.55^{\star *} \\
\pm 2.09\end{array}$ & $\begin{array}{l}40.57^{\star \star} \\
\pm 14.98\end{array}$ & $\begin{array}{l}47.34^{\star *} \\
\pm 15.23\end{array}$ & $\begin{array}{c}15.96^{* *} \\
\pm 4.20\end{array}$ & $\begin{array}{c}11.46^{* *} \\
\pm 2.81 \\
\end{array}$ & $\begin{array}{c}10.95^{\star *} \\
\pm 1.28\end{array}$ & $\begin{array}{l}17.20^{*} \\
\pm 8.08\end{array}$ & $\begin{array}{c}22.53 \\
\pm 14.54 \\
\end{array}$ & $\begin{array}{c}24.26 \\
\pm 14.95 \\
\end{array}$ & \begin{tabular}{|l|}
$49.89^{*}$ \\
\pm 19.70 \\
\end{tabular} & $\begin{array}{l}52.67^{* *} \\
\pm 15.01\end{array}$ & $\begin{array}{l}81.16^{* *} \\
\pm 25.70\end{array}$ & $\begin{array}{l}2.77^{* *} \\
\pm 0.85\end{array}$ & $\begin{array}{l}2.60^{* *} \\
\pm 0.69\end{array}$ & $\begin{array}{l}2.86^{* *} \\
\pm 0.70\end{array}$ \\
\hline h2 & $\begin{array}{r}1.85 \\
\pm 1.41 \\
\end{array}$ & $\begin{array}{l}78.63^{\star \star} \\
\pm 10.08 \\
\end{array}$ & $\begin{array}{c}102.40^{\star \star} \\
\pm 10.25 \\
\end{array}$ & $\begin{array}{c}24.75^{\star \star} \\
\pm 2.83 \\
\end{array}$ & $\begin{array}{c}24.69^{\star \star} \\
\pm 1.89 \\
\end{array}$ & $\begin{array}{c}25.97^{\star \star} \\
\pm 0.86\end{array}$ & $\begin{array}{r}10.59 \\
\pm 5.44 \\
\end{array}$ & $\begin{array}{c}8.33 \\
\pm 9.79\end{array}$ & & $\begin{array}{c}9.78 \\
\pm 13.26 \\
\end{array}$ & $\begin{array}{l}23.37^{*} \\
\pm 10.10 \\
\end{array}$ & \begin{tabular}{|c|}
$55.27^{\star *}$ \\
\pm 17.30 \\
\end{tabular} & $\begin{array}{c}1.01 \\
\pm 0.57\end{array}$ & $\begin{array}{l}2.20^{\star *} \\
\pm 0.46\end{array}$ & $\begin{array}{l}6.78^{\star \star} \\
\pm 0.47\end{array}$ \\
\hline $\mathrm{E}$ & $\begin{array}{c}0.21 \\
\pm 0.34\end{array}$ & $\begin{array}{c}0.35 \\
\pm 2.49\end{array}$ & $\begin{array}{c}0.23 \\
\pm 2.53\end{array}$ & 0.89 & $\begin{array}{ll}0.38 \\
+0.46\end{array}$ & $\begin{array}{c}0.14 \\
\pm 0.21\end{array}$ & $\begin{array}{l}0.01^{\star *} \\
\pm 1.34\end{array}$ & $\begin{array}{c}0.03 \\
\pm 2.42\end{array}$ & $\begin{array}{l}0.02^{\star *} \\
\pm 2.49\end{array}$ & $\begin{array}{c}0.45 \\
\pm 3.28 \\
\end{array}$ & $\begin{array}{c}0.13 \\
\pm 2.50\end{array}$ & $\begin{array}{c}0.29 \\
\pm 4.28 \\
\end{array}$ & $\begin{array}{c}0.19 \\
\pm 0.14\end{array}$ & $\begin{array}{l}0.25^{*} \\
\pm 0.11\end{array}$ & $\begin{array}{c}0.09 \\
\pm 0.11\end{array}$ \\
\hline$[\mathrm{H}$ & 0.960 & 1.901 & 1.844 & 1.534 & 1.633 & 1.582 & 2.317 & 2.534 & 2.538 & 1.805 & 1.524 & 2.218 & 2.157 & 1.693 & 1.475 \\
\hline $\mathrm{H} 2 / 4 \mathrm{H} 1$ & 0.206 & 0.207 & 0.225 & 0.218 & 0.217 & 0.246 & 0.2001 & 0.198 & 0.201 & 0.203 & 0.203 & 0.221 & 0.243 & 0.187 & 0.2003 \\
\hline & & & 1.722 & 1. & & & & 2. & 2.2 & 1 & & 1.433 & 1.219 & & 1.954 \\
\hline Heri & & & & & & & & & & & & & & & 0.331 \\
\hline 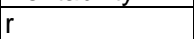 & 0.052 & $-0.858^{\star}$ & $-0.992^{\star \star}$ & -0.558 & $-0.888^{*}$ & -0.713 & -0.483 & $0.870^{*}$ & $0.886^{*}$ & 0.710 & 0.669 & 0.250 & -0.770 & $-0.859^{*}$ & 0.250 \\
\hline
\end{tabular}

*and ${ }^{\star \star}$ significant at 0.05 and 0.01 levels of probability respectively. 

J.Agric.Chem.and Biotechn., Mansoura Univ.Vol. 5 (8): 201 - 213, 2014

Table 4 : Cont.

\begin{tabular}{|c|c|c|c|c|c|c|c|c|c|c|c|c|c|c|c|}
\hline \multirow{2}{*}{\begin{tabular}{|l|} 
Genetic \\
component
\end{tabular}} & \multicolumn{3}{|c|}{ Number of spikes/plant } & \multicolumn{3}{|c|}{ Number of grains/ spike } & \multicolumn{3}{|c|}{ 1000-grain weight (g) } & \multicolumn{3}{|c|}{ Grain yield / plant (g) } & \multicolumn{3}{|c|}{ Grain protein content (\%) } \\
\hline & \begin{tabular}{|c|}
25 \\
$\mathrm{kgN} / \mathrm{fed}$
\end{tabular} & \begin{tabular}{|c|}
50 \\
$\mathrm{kgN} / \mathrm{fed}$
\end{tabular} & $\begin{array}{c}75 \\
\mathrm{kgN} / \mathrm{fe} \\
\text { d }\end{array}$ & $\begin{array}{c}25 \\
\mathrm{kgN} / \mathrm{fe} \\
\mathrm{d}\end{array}$ & $\begin{array}{c}50 \\
\mathrm{~kg} / \mathrm{fed}\end{array}$ & $\begin{array}{c}75 \\
\mathrm{Kg} \\
\mathrm{N} / \mathrm{fed}\end{array}$ & \begin{tabular}{|c|}
25 \\
$\mathrm{kgN} / \mathrm{fed}$
\end{tabular} & \begin{tabular}{|c|}
50 \\
$\mathrm{kgN} / \mathrm{fed}$
\end{tabular} & $\begin{array}{c}75 \\
\mathrm{kgN} / \mathrm{fed}\end{array}$ & $\begin{array}{c}25 \\
\mathrm{kgN} / \mathrm{fe} \\
\mathrm{d}\end{array}$ & $\begin{array}{c}50 \\
\mathrm{~kg} / \mathrm{fed}\end{array}$ & $\begin{array}{c}75 \\
\mathrm{kgN} / \mathrm{fe} \\
\mathrm{d}\end{array}$ & $\begin{array}{c}25 \\
\mathrm{kgN} / \mathrm{fed}\end{array}$ & $\begin{array}{c}50 \\
\mathrm{kgN} / \mathrm{fed}\end{array}$ & $\begin{array}{c}75 \\
\mathrm{kgN} / \mathrm{fed}\end{array}$ \\
\hline 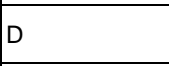 & 4 & \pm 0.3 & $\begin{array}{c}3.16 \\
\pm 2.39 \\
\end{array}$ & $\begin{array}{c}5.91 \\
\pm 4.57 \\
\end{array}$ & $\underline{-1}$ & $\begin{array}{r}13.92 \\
\pm 14.45 \\
\end{array}$ & \pm 1.24 & & & \begin{tabular}{c|}
$11.31^{* *}$ \\
\pm 3.69
\end{tabular} & $\begin{array}{c}6.56 \\
\pm 6.27 \\
\end{array}$ & $\begin{array}{c}10.97 \\
\pm 11.39\end{array}$ & & & \\
\hline & & & & & & & & & & & & $\begin{array}{c}9.32 \\
\pm 27.82 \\
\end{array}$ & & & \\
\hline H1 & & & $\begin{array}{c}24.39^{* *} \\
\pm 6.07\end{array}$ & & $\begin{array}{c}40.36^{* \star} \\
\pm 8.64\end{array}$ & & & & & \begin{tabular}{|c|}
$39.54^{* *}$ \\
\pm 9.36 \\
\end{tabular} & & $\begin{array}{l}93.74^{* *} \\
\pm 28.91\end{array}$ & & & \\
\hline 12 & & & $\begin{array}{c}18.04^{* \star} \\
\pm 5.42\end{array}$ & $\begin{array}{l}45.55^{\star *} \\
\pm 10.38\end{array}$ & $\begin{array}{c}33.04^{\star *} \\
\pm 7.72\end{array}$ & $\begin{array}{c}161.17^{* *} \\
\pm 32.77\end{array}$ & $\begin{array}{l}8.19^{* *} \\
\pm 2.82\end{array}$ & & & \begin{tabular}{|c|}
$37.27^{* *}$ \\
\pm 8.36
\end{tabular} & $\begin{array}{l}45.47^{\star \star} \\
\pm 14.23\end{array}$ & $\begin{array}{l}80.06^{\star \star} \\
\pm 25.83\end{array}$ & & & \\
\hline 2 & & & & & & $\begin{array}{c}32.85 \\
\pm 22.05 \\
\end{array}$ & & & & & & $\begin{array}{c}0.53 \\
\pm 17.38\end{array}$ & & & \\
\hline & & & & & & & & & & & & 0.20 & & & \\
\hline & & & & & & & & & & & & תחקר & & & \\
\hline & & & & & & 0.2 & 0.237 & & & 5 & 0.2 & 0.213 & & & $\frac{0.194}{2181}$ \\
\hline & & & 0.450 & 0.222 & & & & & & & & $\begin{array}{l}1.340 \\
0.274\end{array}$ & & & $\begin{array}{l}2.181 \\
0.447\end{array}$ \\
\hline & -0.125 & 0.554 & 0.144 & 0.541 & 0.459 & 0.062 & -0.313 & -0.431 & 0.026 & 0.895 & 0.109 & -0.334 & 0.635 & 0.969 & 0.054 \\
\hline
\end{tabular}

${ }^{*}$ and $^{\star \star}$ significant at 0.05 and 0.01 levels of probability respectively. 
Gebrel,E.M.A.H. et al.

- 2 - 
J.Agric.Chem.and Biotechn., Mansoura Univ.Vol. 5 (8): 201 - 213, 2014

Table 3: The genotypes mean performance under the three different nitrogen fertilization levels for all traits studied.

\begin{tabular}{|c|c|c|c|c|c|c|c|c|c|c|c|c|c|c|c|}
\hline \multirow[b]{2}{*}{ Genotypes } & \multicolumn{3}{|c|}{ Days to heading (day) } & \multicolumn{3}{|c|}{ Days to maturity(day) } & \multicolumn{3}{|c|}{ Grain filling period(day) } & \multicolumn{3}{|c|}{ Plant height (cm) } & \multicolumn{3}{|c|}{ Main spike length $(\mathrm{cm})$} \\
\hline & $\begin{array}{c}25 \\
\mathrm{kgN} / \mathrm{fe} \\
\mathrm{d}\end{array}$ & $\begin{array}{c}50 \\
\mathrm{kgN} / \mathrm{fe} \\
\mathrm{d}\end{array}$ & $\begin{array}{c}75 \\
\mathrm{kgN} / \mathrm{fe} \\
\mathrm{d}\end{array}$ & $\begin{array}{c}25 \\
\mathrm{kgN} / \mathrm{fe} \\
\mathrm{d}\end{array}$ & $\begin{array}{c}50 \\
\mathrm{kgN} / \mathrm{fe} \\
\mathrm{d}\end{array}$ & $\begin{array}{c}75 \\
\mathrm{kgN} / \mathrm{fe} \\
\mathrm{d}\end{array}$ & $\begin{array}{c}25 \\
\mathrm{kgN} / \mathrm{fe} \\
\mathrm{d}\end{array}$ & $\begin{array}{c}50 \\
\mathrm{kgN} / \mathrm{fe} \\
\mathrm{d}\end{array}$ & $\begin{array}{c}75 \\
\mathrm{kgN} / \mathrm{fe} \\
\mathrm{d}\end{array}$ & $\begin{array}{c}25 \\
\mathrm{kgN} / \mathrm{fe} \\
\mathrm{d}\end{array}$ & $\begin{array}{c}50 \\
\mathrm{kgN} / \mathrm{fe} \\
\mathrm{d}\end{array}$ & $\begin{array}{c}75 \\
\mathrm{kgN} / \mathrm{fe} \\
\mathrm{d}\end{array}$ & $\begin{array}{c}25 \\
\mathrm{kgN} / \mathrm{fe} \\
\mathrm{d}\end{array}$ & $\begin{array}{c}50 \\
\mathrm{kgN} / \mathrm{fe} \\
\mathrm{d}\end{array}$ & $\begin{array}{c}75 \\
\mathrm{kgN} / \mathrm{fe} \\
\mathrm{d}\end{array}$ \\
\hline Mis & 93.57 & 99.75 & 104.49 & 143.62 & 147.76 & 153.14 & 50.47 & 49.36 & \begin{tabular}{|l|l|}
47.50 \\
\end{tabular} & 99.80 & 104.04 & 111.55 & 11.63 & 13.54 & 12.60 \\
\hline Giza 168 & 96.82 & 100.63 & 106.53 & 145.66 & 148.79 & 151.94 & 50.41 & 48.34 & 45.66 & 96.99 & 101.79 & 108.91 & 12.35 & 12.31 & 14.36 \\
\hline Shandaweel 1(P3) & 89.67 & 92.55 & 99.04 & 143.76 & 146.79 & 151.72 & 4.16 & 53.53 & 51.73 & 108.86 & 14.27 & 16.48 & 13.60 & 14.78 & 16.12 \\
\hline Gemmeiza 9 (P4) & 95.63 & 100.81 & 105.79 & 146.90 & 150.99 & 155.91 & 51.23 & 50.44 & 47.57 & 99.61 & 105.31 & 111.71 & 12.30 & 13.42 & 14.60 \\
\hline \begin{tabular}{|ll} 
Sids 1 & (P5) \\
\end{tabular} & 95.85 & 101.49 & 106.42 & 151.03 & 152.89 & 154.88 & 54.48 & 51.47 & 48.34 & 97.77 & 100.98 & 103.87 & 12.66 & 11.77 & 12.70 \\
\hline Sakha 94 & 89.64 & 94.79 & 97.59 & 143.87 & 147.88 & 150.15 & 54.32 & 53.38 & 50.24 & 103.22 & 110.97 & 113.96 & 10.96 & 11.68 & 13.71 \\
\hline $\mathrm{P}_{1} \times \mathrm{P}_{2}$ & 93.68 & 102.59 & 112.27 & 147.86 & 152.98 & 156.77 & 54.30 & 50.46 & 46.47 & 97.08 & 100.50 & 104.82 & 14.55 & 14.42 & 15.11 \\
\hline $\mathrm{P}_{1} \times \mathrm{P}_{3}$ & 92.71 & 100.58 & 104.85 & 149.83 & & 156.95 & 57.49 & & 50.69 & 103.25 & 105.18 & & 11.97 & 13.46 & 15.55 \\
\hline $\mathrm{P}_{4} \times \mathrm{P}_{1}$ & 95.24 & 101.46 & 107.60 & 148.91 & 151.87 & 154.90 & 53.50 & 49.50 & 46.33 & 104.69 & 107.92 & 110.84 & 11.53 & 12.46 & 14.01 \\
\hline$P_{1} \times P_{5}$ & 96.34 & 103.60 & 109.96 & 149.79 & 153.57 & 156.85 & 53.44 & 49.44 & 46.61 & 91.14 & 95.68 & 96.88 & 13.45 & 14.55 & 15.38 \\
\hline$P_{6} \times P_{1}$ & 95.28 & 102.52 & 107.71 & 150.15 & 152.12 & 155.77 & 54.42 & 49.48 & 46.79 & 99.67 & 102.52 & 106.73 & 10.75 & 12.44 & 15.27 \\
\hline $\mathrm{P}_{3} \times \mathrm{P}_{2}$ & 92.48 & 102.46 & 106.43 & 14 & 152.15 & 154.88 & 56.33 & & 47.38 & .51 & 88 & & 13.14 & 13.65 & 5.61 \\
\hline $\mathrm{P}_{4} \times \mathrm{P}_{2}$ & 97.32 & 104.68 & 109.77 & 150.82 & 153.92 & 156.92 & 53.48 & 5 & 7.14 & 96.92 & & 60 & 12.82 & 13.74 & 14.82 \\
\hline $\mathrm{P}_{5} \times \mathrm{P}_{2}$ & & & & & & 62 & & & & & & & & 13.42 & 14.88 \\
\hline $\mathrm{P}_{6} \times \mathrm{P}_{2}$ & 95.67 & 103.19 & 108.91 & 147.87 & 150.87 & 152.87 & 52.42 & 47.57 & 43.63 & 101.50 & 105.28 & 109.52 & 12.85 & 14.41 & .33 \\
\hline $\mathrm{P}_{3} \times \mathrm{P}_{4}$ & 93.20 & & 109.17 & & 152.87 & 155.91 & & & & & & & & 14.37 & 16.32 \\
\hline$P_{5} \times P_{3}$ & 92.37 & 107.32 & 112.12 & 150.96 & 153.39 & 157.86 & 58.34 & 49.68 & 46.54 & 91.02 & 96.89 & 97.23 & 13.64 & 14.61 & 15.62 \\
\hline $\mathrm{P}_{3} \times \mathrm{P}_{6}$ & 93.41 & 107.52 & 112.80 & 142.90 & 146.75 & 152.86 & 49.24 & 42.49 & 39.54 & 102.67 & 106.69 & 109.59 & 13.05 & 14.33 & 16.24 \\
\hline $\mathrm{P}_{4} \times \mathrm{P}_{5}$ & 95.35 & 107.82 & 113.36 & 151.20 & 153.37 & 159.86 & 55.52 & 48.50 & 45.61 & 98 & 104.54 & 73 & 12.73 & 12.97 & 15.60 \\
\hline $\mathrm{P}_{4} \times \mathrm{P}_{6}$ & 91.30 & 99.51 & 106.43 & 146.74 & 150.23 & 156.49 & 54.27 & 50.45 & 48.21 & 101.76 & 107.93 & 110.60 & 13.60 & 14.04 & 16.45 \\
\hline $\mathrm{P}_{5} \times \mathrm{P}_{6}$ & 95.41 & 102.38 & 108.77 & 146.54 & 152.42 & 154.79 & 53.44 & 50.62 & 46.11 & 103.49 & 107.51 & & 13.37 & 14.67 & 16.58 \\
\hline $\begin{array}{ll}\text { L.S.D } & 0.05\end{array}$ & 1.30 & 1.69 & 1.38 & 2.00 & 1.78 & 1.06 & 0.26 & 0.48 & 0.37 & 1.92 & 1.04 & 1.54 & 1.25 & 1.42 & 0.87 \\
\hline
\end{tabular}

\section{and ${ }^{* *}=$ Significant at 0.05 and 0.01 levels of probability, respectively.}

Table 3: Cont.

\begin{tabular}{|c|c|c|c|c|c|c|c|c|c|c|c|c|c|c|c|}
\hline \multirow[b]{2}{*}{ Genotypes } & \multicolumn{3}{|c|}{ Number of spikes/plant } & \multicolumn{3}{|c|}{ Number of grains/ spike } & \multicolumn{3}{|c|}{1000 -grain weight $(\mathrm{g})$} & \multicolumn{3}{|c|}{ Grain vield / plant (q) } & \multicolumn{3}{|c|}{ Grain protein content $(\%)$} \\
\hline & $\begin{array}{c}25 \\
\mathrm{kgN} / \mathrm{fed}\end{array}$ & $\begin{array}{c}50 \\
\mathrm{kgN} / \mathrm{fed}\end{array}$ & $\begin{array}{c}75 \\
\mathrm{kgN} / \mathrm{fed}\end{array}$ & $\begin{array}{c}25 \\
\mathrm{kgN} / \mathrm{fed}\end{array}$ & $\begin{array}{c}50 \\
\mathrm{kgN} / \mathrm{fed}\end{array}$ & $\begin{array}{c}75 \\
\mathrm{kgN} / \mathrm{fed}\end{array}$ & $\begin{array}{c}25 \\
\mathrm{kgN} / \mathrm{fed}\end{array}$ & $\begin{array}{c}50 \\
\mathrm{kgN} / \mathrm{fed}\end{array}$ & $\begin{array}{c}75 \\
\mathrm{kgN} / \mathrm{fed}\end{array}$ & $\begin{array}{c}25 \\
\mathrm{kgN} / \mathrm{fed}\end{array}$ & $\begin{array}{c}50 \\
\mathrm{kgN} / \mathrm{fed}\end{array}$ & $\begin{array}{c}75 \\
\mathrm{kgN} / \mathrm{fed}\end{array}$ & $\begin{array}{c}25 \\
\mathrm{kgN} / \mathrm{fed}\end{array}$ & $\begin{array}{c}50 \\
\mathrm{kgN} / \mathrm{fed}\end{array}$ & $\begin{array}{c}75 \\
\mathrm{kgN} / \mathrm{fed}\end{array}$ \\
\hline (P1) & & & & & & & & & & & & \begin{tabular}{|l}
56.91 \\
\end{tabular} & & & \\
\hline $\begin{array}{ll}\text { Giza } 168 & \text { (P2) } \\
\end{array}$ & 17.87 & 21.86 & 24.40 & 73.92 & 81.86 & 94.67 & 38.92 & 42.32 & 45.90 & 37.86 & 44.04 & 57.93 & 6.67 & 10.25 & 12.37 \\
\hline Shandaweel 1 (P3) & 17.40 & 22.33 & 27.25 & 77.19 & 84.51 & 96.65 & 42.67 & 43.90 & 48.92 & 44.80 & 46.80 & 49.90 & 8.61 & 10.46 & 13.40 \\
\hline Gemmeiza 9 (P4) & 22.40 & 25.07 & 27.84 & 72.77 & 84.67 & 93.76 & 38.72 & 43.56 & 46.97 & 45.84 & 49.13 & 59.13 & 8.32 & $\frac{10.40}{9.75}$ & $\frac{10.40}{11.55}$ \\
\hline Sids $1 \quad(\mathrm{P5})$ & 20.64 & 24 & 28.52 & 76.44 & 84 & 95.82 & 33.15 & 36.79 & 40.92 & 43.89 & 51.05 & 54.75 & 53 & 9.71 & 11.60 \\
\hline \begin{tabular}{|ll} 
Sakha 94 & $(\mathrm{P} 6)$ \\
\end{tabular} & 22.42 & 25 & 29.72 & 70.28 & & 86.64 & 37.78 & & & 44 & 47 & 53.78 & & 7.70 & 10.33 \\
\hline & 20.26 & & & 75.08 & & & 37.08 & & & 36. & & 51. & & & 11.42 \\
\hline & 22.60 & & & 77.89 & & & 38. & & & & & & & & 12.49 \\
\hline & & & & & & & 42 & & & & & 58.2 & & & 13.41 \\
\hline$\frac{14 \times 1}{P_{1} \times P_{5}}$ & 22.43 & 25 & & & & & & & & & & & & & 11.52 \\
\hline $\mathrm{P}_{6} \times \mathrm{P}_{1}$ & 21.82 & 23 & 34 & 70 & & & 37 & & & & & 52. & & & 11.56 \\
\hline $\mathrm{P}_{3} \times \mathrm{P}_{2}$ & 17.58 & 22. & & 68.79 & & & & & & & & 62.04 & 7.73 & 10.40 & 12.51 \\
\hline $\mathrm{P}_{4} \times \mathrm{P}_{2}$ & 22.64 & 23. & 30.54 & 79.43 & & & & & & 45 & 50.85 & 59.71 & 7.59 & 10.42 & 12.44 \\
\hline $\mathrm{P}_{5} \times \mathrm{P}_{2}$ & 18.73 & 21. & 22. & 76.58 & & & & & & & 43.60 & 58.38 & 8.30 & & 12.53 \\
\hline$P_{6} \times P$ & 21.10 & 22. & 24. & 77.58 & & & & & & 41.78 & & 48. & 7.53 & & 11.52 \\
\hline$P_{3} \times \mathrm{P}$ & 23.82 & 24.34 & 28.98 & 70.33 & & & 42.10 & & & 46. & 50.04 & 53. & 9.24 & & 12.50 \\
\hline$P_{5} \times P_{3}$ & 22.27 & 24.03 & 27.48 & 81.10 & 90 & 106 & 39.03 & & & 42.92 & 50.54 & 54.3 & 8.59 & 10.44 & 12.32 \\
\hline$P_{3} \times P$ & 17.72 & 24.91 & 27.12 & 72.42 & 80 & 101.19 & 41.84 & 44 & 49 & 39.24 & 46. & 54. & 8.41 & 10.53 & 11.65 \\
\hline$P_{4} \times P_{5}$ & 21.80 & 24.77 & 29.42 & 73.02 & 88 & $10 \mathrm{~s}$ & 36.82 & & 42 & 44 & 53. & 55. & 7. & 10 & 11.62 \\
\hline$P_{4} \times P_{6}$ & 23.19 & 25.72 & 31.56 & 75.07 & 84.03 & 95 & 39.01 & 43 & 47 & 43 & 52. & 57. & 9 & 10 & 12.50 \\
\hline $\begin{array}{l}\frac{4}{4} \times r_{6} \\
5_{5} \times P_{6}\end{array}$ & $\frac{20.15}{21.75}$ & $\frac{20.12}{25.23}$ & $\begin{array}{l}23.70 \\
23.79\end{array}$ & 77.30 & $\frac{04}{82}$ & $\frac{57}{87}$ & $\begin{array}{l}3.01 \\
36.91\end{array}$ & & $\frac{4}{4}$ & $\frac{45}{41}$ & 42 & 45. & $\begin{array}{l}8.05 \\
8.44\end{array}$ & 10. & $\frac{1.50}{11.60}$ \\
\hline 0.5 & 1.97 & 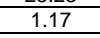 & 1.02 & & & & & & & & 0.27 & & & & 0.28 \\
\hline S.D & 2.61 & 1.55 & 1.35 & 2.30 & 1.47 & 1.19 & 1.95 & 1.7 & 1.3 & 0.44 & 0.35 & 0.37 & 0.44 & 0.3 & 0.37 \\
\hline
\end{tabular}

${ }^{\star}$ and $^{* \star}=$ Significant at $\mathbf{0 . 0 5}$ and 0.01 levels of probability, respectively. 
Gebrel,E.M.A.H. et al.

- 2 - 